Korinek could have approached both as examples of many Canadians' moral panic over the rise in unwanted pregnancy among young, single, white, middle-class girls during the socalled sexual revolution. ${ }^{3}$

In and of itself, Korinek's book is a valuable contribution to the history of feminism in Canada. But it is best read alongside other works dealing with North American women in the fifties and sixties. Together, these texts point to the growing consensus over the enormous significance of the swell before the feminist second wave. ${ }^{4}$

Christabelle Sethna

University of Ottawa

\title{
Ninette Kelley and Michael Trebilcock. The Making of the Mosaic: A History of Canadian Immigration Policy. Toronto: University of Toronto Press, 1998. Pp. viii, 621.
}

Ninette Kelley and Michael Trebilcock set out to accomplish the formidable task of uncovering the history of immigration policy in Canada over four centuries, focusing on the last 150 years. In 621 pages the authors seek to identify who was allowed in to Canada and who was not, and the reasons for these decisions. The focus of the book is on describing and

3 Christabelle Sethna, “'WE WANT FACTS NOT MORALS!' Unwanted Pregnancy, the Toronto Women's Caucus and Sex Education,” in Ontario Since Confederation: A Reader, ed. Lori Chambers and Edgar-Andre Montigny (Toronto: University of Toronto Press, 2000), 409-28.

4 For example, see Wini Breines, Young, White and Miserable: Growing Up Female in the Fifties (Boston: Beacon Press, 1992); Dan Horowitz, Betty Friedan and the Making of the Feminine Mystique: The American Left, the Cold War, and Modern Feminism (Amherst: University of Massachusetts Press, 1998); Ruth Rosen, The World Split Open: How the Modern Women's Movement Changed America (New York: Penguin, 2001 [2000]); Doug Owram, Born at the Right Time: A History of the Baby Boom Generation (Toronto: University of Toronto Press, 1996); Barbara M. Freeman, The Satellite Sex: The Media and Women's Issues in English Canada, 1966-1971 (Waterloo, Ont.: Wilfrid Laurier University Press, 2001). 
interpreting the way particular events, various participants, selected ideologies, and the federal and provincial governments shaped government policies. The authors demonstrate how for most of the history of immigration, policy-making generally proceeded by way of executive and administrative directives rather than legislative action. As a consequence, until the 1960s, regulation and the exercise of administrative discretion largely marginalized the impact of more diverse interests, with the exception of economic interests, which were a dominant influence on immigration policy.

As a second accomplishment, Kelley and Trebilcock reveal the impact on Canadian immigration policies of federal and regional government divisions, which reflect a shared jurisdiction over immigration policy in section 95 of the British North American Act of 1867 (with the federal government paramount). To support this claim the authors document a series of cases, as when British Columbia urged politicians to restrict Asian immigration in the early twentieth century and to intern Japanese Canadians during the Second World War, and again in Quebec, when the federal government responded to pressures over non-francophone immigration before and during the Second World War.

The authors should be congratulated for their effort to cover the Canadian mosaic by assessing the influence of region, race, gender, class, and ethnicity on immigration policy. For example, the chapter on the years 1930 to 1937 discusses the government's admission restrictions on Asians, the increase in naturalization refusals and revocations, and the deportation of 25,000 people, including political radicals and labour agitators. Specifically, we learn that the law restricting Chinese immigration (Chinese Immigration Act of 1923) remained in force, and between 1930 and 1935 only three Chinese persons emigrated to Canada. The less restrictive Japanese immigration laws set a limit of 150 persons annually allowed into Canada. Moreover, the entry of all other persons of "any Asiatic race" was expressly prohibited, with the exception of wives and minor children of Canadian citizens who were able to care for them. 
The chronological organization of chapters facilitates the selection of sections to cover a particular period of time (the depression years, the post-war boom). While on the one hand periodization is beneficial for viewing trends and events across time and place, on the other hand this approach can also overshadow the overarching themes of liberalism and community that are outlined in the introduction and then reassessed in the conclusion. Hence, chapters tend to address the details of the expansion, restrictions and contraction of immigration policies within particular economic, political and cultural circumstances, without explicitly linking these insights to the overall thematic structure. That said, this study does not lack for analysis or integration of ideas with the research. The chapters on the last fifty years, for example, are particularly useful for understanding the background to current refugee policies, the historical representations of various groups (the Japanese-Canadian Citizenship Association and the Canadian Jewish Congress), and the fundamental restructuring of immigration policy as a consequence of the introduction of the point system.

The study is based on a wide range of primary sources including statutes, case law, government records, debates, and newspapers. The comprehensive discussion of legal cases and legislation is readable and does not assume a legal background, making it accessible to non-specialists. As well, extensive readings of government papers provide important insights into the dynamics of Canadian federalism, in particular the role of the executive, civil servants, and cabinet ministers. Unfortunately, many of the statistics highlighting significant increases and declines in migration patterns are included only in the text; a series of graphs and figures would have sharpened the contrasts and continuities that these numbers are intended to convey to the reader.

As stated in the introduction, this book is a "history of immigration policy, not the social or cultural histories of various immigrant groups who have settled in Canada" (p. 4). Hence, based on the sources that were consulted for the research, dominant voices in the book are those of government officials 
and the occasional union or ethnic leader. As such, it is an important companion piece to many of the recent histories of immigration that focus on settlement trends and the relationships between and among local, ethnic and racial communities.

Those who teach Canadian history, political science, and law will find within this monograph a wealth of detailed information and a vast source of references to primary sources for further study. Researchers will benefit from the concise laying out of the historical overview of immigration policies. This monograph represents an example of comprehensive research and thoughtful analysis. Within contemporary debates on immigration and multiculturalism in Canada it serves as a critical reminder to Canadians of how acceptance and exclusion of immigrants and refugees have shaped the mosaic.

Lorna R. McLean

University of Ottawa

Vera K. Fast, ed. Companions of the Peace: Diaries and Letters of Monica Storrs, 1931-1939. Toronto: University of Toronto Press, 1999. Pp. 243.

Delving into the history of British Columbia's Peace River region in the decade before World War II without encountering Anglican missionary Monica Storrs is a near-impossibility. Storrs and her seemingly bottomless supply of energy and commitment to spreading the Anglican gospel and through it, her own version of English culture and civilization, are constants. Often engaged in organizing Boy Scout and Girl Guide troops along with church services and functions, the equestrienne Storrs crossed and re-crossed the expansive north Peace country in the waning day of the settlement frontier before the war, the Alaska highway, and mid-century North American culture forever changed the last, best, west. And in completing an editorial project first undertaken by W.L. Morton in the late 1970s, Vera 